\title{
Hepatitis C Virus Diagnosis in Prospective Blood Donors: Epidemiology, Optimal Testing Approach and Treatment Cut-offs
}

\section{Amilo Grace Ifechukwudebelu ${ }^{1}$, Fasakin Kolawole Asimiyu ${ }^{2 *}$, Ifeanyichukwu Martins Ositadima ${ }^{3}$}

${ }^{1}$ Department of Haematology, College of Medicine, Nnamdi Azikiwe University Teaching Hospital, Nnewi, Nigeria

${ }^{2}$ Department of Haematology, Federal Teaching Hospital, Ido Ekiti, Nigeria

${ }^{3}$ Department of Medical Laboratory Science, Faculty of Health Science and Technology, Nnewi Campus, Nnamdi Azikiwe University, Awka, Nigeria

*Corresponding Author

Fasakin Kolawole Asimiyu

Chief Biomedical Scientist/Lecturer

Department of Haematology

Federal Teaching Hospital

Ido Ekiti

Nigeria

Cell no. +2347031890651

Email: fasakin_kolawole@yahoo.co.uk

Received: 28 February 2017; | Revised: 30 March 2017; | Accepted: 25 May 2017

\begin{abstract}
Hepatitis $\mathrm{C}$ virus (HCV) infection has been noted a major public health problem with no vaccines available currently. This study aims at optimizing 'safe blood' practice by advancing HCV testing beyond Diaspot rapid enzyme immunoassay in current use in Nigerian Health Institutions. Between August, 2014 and November, 2015, a total of 300 blood donors' plasma samples were screened with both Diaspot and HCV Ag-Ab enzyme-linked immunosorbent assay techniques. HCV-RNA confirmation and quantification were performed with real-time polymerase chain reaction (PCR). Alanine aminotransferase (ALT) was performed on confirmed positive blood donor for treatment purpose. The overall gender ratio and mean age of blood donors screened for HCV were 1.5:1 and 27.67 \pm 7.77 years respectively. Of the 300 blood donors screened, $5(1.67 \%)$ and $1(0.33 \%)$ were seropositive for HCV on the basis of Diaspot and enzyme-linked immunosorbent assay (ELISA) techniques respectively. Diagnostic odds ratio showed that ELISA is nearly 9-fold a better diagnostic tool compared to Diaspot technique. Real-time PCR assay confirmed positivity of 1 $(0.33 \%)$ of the blood donor for hepatitis C. HCV-RNA viral load and plasma ALT of the lone sample were 133, $209 \mathrm{IU} / \mathrm{mL}$ and 11.1 IU/L respectively. HCV prevalence among blood donors in Ekiti state is low, $0.33 \%$. Enzyme-linked immunosorbent assay technique should be the starting point of HCV serologic screening and a surrogate technique for real-time PCR. The development of workable algorithm to reduce risks associated with blood transfusion and enhances both blood donors' and recipients' safety is highly imperative.
\end{abstract}

Keywords: Hepatitis C virus, prospective blood donors, Diagnosis, Diaspot, Real-time PCR 


\section{Introduction}

Hepatitis C Virus (HCV) is a major public health problem and a leading cause of chronic liver disease worldwide ${ }^{[1-2]}$. It is a single-stranded positive-sense RNA virus with a diameter of about $50 \mathrm{~nm}$, and a genome of approximately 9.6 kilobases ${ }^{[3]}$. HCV belongs to the genus Hepacivirus in the family of Flaviridae. HCV is more than four-fold infectious compared to human immunodeficiency (HIV) virus and requires less exposure than HIV to cause infection ${ }^{[4]}$. Studies revealed that more than 10 types and 70 subtypes of HCV genotype has been described ${ }^{[5]}$ and recent study reported type 1 and 2 in Nigerian subjects ${ }^{[6]}$. HCV has seven nonstructural proteins which include p7, NS2, NS3, NS4A, NS4B, NS5A and NS5B. The structural proteins form the viral particle and include the core protein and the envelope glycoproteins E1 and E2 [7]. Owing to its rapid replication and the high rate of error insertion of the RNA-dependent RNA polymerase, HCV spontaneously mutates within a given infected individual to form a related but distinct "quasispecies ${ }^{[8]}$. The generation of these mutants appears to be one of the key mechanisms by which HCV escape the host's immune response, maintaining persistent infection ${ }^{[9]}$. Very importantly, the replication cycle of the $\mathrm{HCV}$ occurs totally in the cytoplasm and - once the replication is stopped - the virus can be cleared from the cells and thus the infection definitively cured.

\subsection{HCV epidemiology and mortality reports}

An estimated 170 million people are infected with HCV globally and annually, 3-4 million new $\mathrm{HCV}$ infections are reported yearly. Almost 500,000 individuals were estimated to have died from HCV-related liver disease in $2010^{[10]} .75-85 \%$ of newly infected persons develop chronic infections and $60-70 \%$ of chronically infected persons develop chronic liver disease, 5-20\% develops cirrhosis, $1-5 \%$ dies from liver cirrhosis or cancer ${ }^{[11]}$. In many of the developed countries, $\mathrm{HCV}$ prevalence is $<2 \%$ including the United States of America and $\geq 2 \%$ in some countries in Africa. An overall regional HCV prevalence of $5.3 \%$ and approximately 32 million people have been reported in Africa according to the World Health Organization with Egypt being the leading country with $\mathrm{HCV}$ prevalence of $17.5 \%{ }^{[3]}$. In $25 \%$ of liver cancer patients, the underlying cause is $\mathrm{HCV}$. HCV in the Western region of Africa including Nigeria is considered to be highly endemic.

\subsection{HCV transmission routes and blood transfusion risks}

Direct percutaneous inoculation has been recognized as the most efficient mode of transmission of $\mathrm{HCV}$ in regions with $\geq 2 \% \mathrm{HCV}$ prevalence ${ }^{[12]}$. Transfusion of blood and blood products, sexual and vertical transmission, tattooing as well as medical and surgical risk factors has been reported ${ }^{[13-17]}$. In Africa for instance, only 19\% of blood is being screened for blood transfusion due to limited resources and cost of laboratory tests and posts a lot of risks for recipients of blood transfusion ${ }^{[18]}$. Intravenous drug injection is the most common route of $\mathrm{HCV}$ transmission in regions with $<2 \% \mathrm{HCV}$ prevalence. Despite the fact that blood transfusion is known as a risk factor of acquiring $\mathrm{HCV}$ infection, it is still being used as a means of life-saving therapy for myriads of transfusion-dependent patients to reduce morbidity and mortality and save thousands of lives. Although introduction of screening tests for $\mathrm{HCV}$ in blood donors has led to further reduction in $\mathrm{HCV}$ transmission through blood and blood products, it still remains a public health problem. Lack of vaccine, the inconsistency in screening procedures, lack of confirmatory diagnosis in blood donors due to associated costs and long turnaround time, and non-availability of workable algorithm for $\mathrm{HCV}$ as for HIV testing have led to possible variations in reports including under-diagnosis and underreporting as well as over-estimated $\mathrm{HCV}$ endemicity among blood donors from country to country ${ }^{[7,19-23]}$. Most hepatitis $\mathrm{C}$ viral diagnosis in Nigeria has been on the basis of detectable antibodies to the virus in human serum or plasma by Diaspot technique with varied conclusions ${ }^{[19,24-26]}$. This study is aimed at advancing HCV screening beyond Diaspot rapid technique by testing with the third generation Genscreen HCV Ag-Ab Monolisa kit by ELISA technique and confirming diagnosis 
with Real-time PCR. Alanine aminotransferase (ALT) was performed for confirmed blood donors for treatment purpose.

\section{Materials and Methods}

\subsection{Sample collection, storage and transportation}

Five millilitres $(5 \mathrm{~mL})$ of K3EDTA anticoagulated samples were collected from prospective blood donors following an informed consent. Plasma was separated according to Clinical and Laboratory Standard Institute's guideline [26] and aliquot into three separate plain containers. Samples not run immediately were frozen at - 40 to $-70^{\circ} \mathrm{C}$ and transported in cold chain till analysis.

\subsection{Study design}

This is a descriptive cross-sectional study meant to evaluate the epidemiology of hepatitis $\mathrm{C}$ virus among prospective blood donors and establish diagnosis through confirmation of $\mathrm{HCV}$ status with advanced techniques.

\subsection{HCV diagnosis}

Anti-HCV antibody screening was performed with Diaspot rapid technique and subsequently repeated with ELISA technique using Genscreen $\mathrm{HCV}$ Ag-Ab Monolisa kit (Biorad, Marnes-laCoquette-France) according to the manufacturers' instructions. Positive/discordant results were confirmed for HCV-RNA with real-time PCR assay. HCV-RNA quantification and plasma ALT were performed for positive sample using real-time PCR quantitative assay and Randox technique respectively. These were performed using the third aliquot plasma sample.

\subsection{Informed consent and ethical clearance}

Prospective blood donors who gave informed consent were administered questionnaires to prospective blood donors to obtain their social demographic characteristics and research information. Ethical clearance was obtained from the Ethics and Research Committee of the Federal Teaching Hospital, Ido Ekiti.

\subsection{Statistical analysis}

Results were analyzed using mean and standard deviation, percentage, t-test of the Statistical Package for Social Sciences (SPSS Inc., Chicago, USA)

\section{Results}

3.1 Gender ratios, age groups, religious and educational status of prospective blood donors screened for HCV antibody

Between August 2014 and November, 2015, 300 of the prospective blood donors were screened for hepatitis $\mathrm{C}$ virus antibody using Diaspot onestep enzyme immunoassay (EIA) and repeated with Genscreen HCV Ag-Ab technique. 222 (74.0\%), 69 $(23.0 \%)$ and $9(3.0 \%)$ of the population screened were voluntary, replacement and paid blood donors respectively. The overall mean age $( \pm \mathrm{SD})$ and male: female ratio of PBD $w 27.67 \pm 7.77$ and 1.5:1. Based on the population of each category of blood donors screened, the mean age $( \pm \mathrm{SD})$ and male: female ratios of VBD, RBD and PDBD were 26.77 \pm 7.79 and $1: 1 ; 30.70 \pm 7.39$ and $10.5: 1 ;$ and 21.22 \pm 0.44 and 3.5:1 respectively. However, comparing the mean age and male: female ratios based on blood donor categories, replacement blood donors had the highest $(30.70 \pm 7.39$ and 10.5:1). Similarly, of the 300 PBD screened, $252(84.0 \%)$ of prospective blood donors were Christians. According to blood donor categories, 185 (83.3\%), $61(88.4 \%)$ and $7(77.8 \%)$ of VBD, RBD and PDBD respectively were Christians while the rest were Islamic faithfuls. Over $84 \%(84.3 \%)$ of the total number of PBD had tertiary education. Only $13.3 \%$ had secondary education. The rest were less than 5\%. Comparing the blood donor categories, predominantly, most VBD $(90.5 \%)$ had tertiary education compared to two-thirds $(66.7 \%)$ of RBD and PDBD. While there were $3(1.4 \%)$ of PBD without formal education among $\mathrm{VBD}$, the least level of education among RBD and PDBD were primary and secondary schools respectively. Table 1 below presented the results. 
3.2 Marital status and blood donation history of prospective blood donors screened for $\mathrm{HCV}$ antibody

Table 2 showed that, overall, nearly $60 \%$ $(58.0 \%)$ of the PBD were singles while $48(16.0 \%)$, $6(2.0 \%)$ and $1(0.3 \%)$ were married, widowed and divorced/separated respectively. 134 (60.4\%), 84 $(37.8 \%), 3(1.4 \%)$ and $1(0.5 \%)$ of VBD were singles, married, widowed and divorced/separated respectively. RBD had a different pattern showing more married individuals than singles $(49.3 \%$ compared to $46.4 \%)$. Only, 3 (4.3\%) were widows. Nearly $90.0 \%$ (88.9\%) of PDBD were singles and 1 (11.1\%) was married. Of the overall PBD, 168 $(56.0 \%)$ were first timers while $132(44.0 \%)$ were previous donors and these were distributed among VBD, RBD and PDBD categories.

Table 1: Gender Ratios, age groups, religious and educational status of blood donors screened for HCV antibody

\begin{tabular}{|c|c|c|c|c|}
\hline Social Demog & Overall PBD n (\%) & VBD n $(\%)$ & RBD n (\%) & PDBD n (\%) \\
\hline \multicolumn{5}{|l|}{$\underline{\operatorname{Sex}}$} \\
\hline Male & 181 & 111 & 63 & 7 \\
\hline Female & 119 & 111 & 6 & 2 \\
\hline Male: Female Ratio & $1.5: 1$ & $1: 1$ & $10.5: 1$ & $3.5: 1$ \\
\hline Mean age $($ Mean \pm SD) & $27.67 \pm 7.77$ & $26.77 \pm 7.79$ & $30.70 \pm 7.39$ & $21.22 \pm 0.44$ \\
\hline \multicolumn{5}{|l|}{ Age Range } \\
\hline $16-25$ & $133(44.3)$ & $108(48.6)$ & $20(29.0)$ & $5(55.6)$ \\
\hline $26-35$ & $112(37.3)$ & $78(35.1)$ & $30(43.5)$ & $4(44.4)$ \\
\hline $36-45$ & $48(16.0)$ & $31(14.0)$ & $17(24.6)$ & $0(0.0)$ \\
\hline $46-55$ & $5(1.7)$ & $3(1.4)$ & $2(2.9)$ & $0(0.0)$ \\
\hline $56-59$ & $2(0.7)$ & $2(0.9)$ & $0(0.0)$ & $0(0.0)$ \\
\hline \multicolumn{5}{|l|}{ Religion: } \\
\hline Christianity & $252(84.0)$ & $185(83.3)$ & $61(88.4)$ & $7(77.8)$ \\
\hline Islam & $48(16.0)$ & $37(16.7)$ & $8(11.6)$ & $2(22.2)$ \\
\hline \multicolumn{5}{|l|}{ Education: } \\
\hline None & $3(1.0)$ & $3(1.4)$ & $0(0.0)$ & $0(0.0)$ \\
\hline Primary & $4(1.3)$ & $1(0.5)$ & $3(4.3)$ & $0(0.0)$ \\
\hline Secondary & $40(13.3)$ & $17(7.7)$ & $20(29.0)$ & $3(33.3)$ \\
\hline Tertiary & $253(84.3)$ & 201(90.5) & $46(66.7)$ & $6(66.7)$ \\
\hline
\end{tabular}

Abbreviation: VBD, Voluntary Blood Donors; RBD, Replacement Blood Donors; PDBD, Paid Blood Donors

3.3 Statistical comparison of the diagnostic accuracy of HCV serologic techniques using AmpliPrep/COBAS TaqMan PCR as the Gold Standard

Table 3 showed the comparison of $\mathrm{HCV}$ antibody results of Diaspot one-step rapid EIA and Biorad HCV Ag-Ab Monolisa assay using statistical indices including diagnostic odds ratio which is known as the single indicator of test performance as well as a measure of the effectiveness of a diagnostic test ${ }^{[27]}$. Diaspot showed that $5(1.67 \%)$ of the PBD were seropositive for HCV antibody. When repeated with Genscreen $\mathrm{HCV} \mathrm{Ag}-\mathrm{Ab}$ Monolisa kit, the result was $1(0.33 \%)$, thus resulting in inconclusive results. Real-time PCR assay was used as the gold standard technique. Sensitivities and negative predictive values of both Diaspot rapid one-step EIA assay and sandwich ELISA assay 
were $100.0 \%$ but they differ in specificities and positive predictive values. The latter had $100.0 \%$ specificity while the former had $99.70 \%$. Similarly, the latter had PPV of $100.0 \%$ while the former technique had $20.0 \%$. The result was further validated with the use of diagnostic odds ratio which was independence of prevalence. Diagnostic odds ratios (DORs) for both techniques were undefined but both false positives and false negatives were zero for Genscreen $\mathrm{HCV} \mathrm{Ag}-\mathrm{Ab}$ Monolisa assay (indicating a perfect test) while only false negatives were zero for Diaspot one step EIA. On adding 0.5 to all cells in the contingency table (to minimize bias that might be introduced), Sandwich ELISA showed similar sensitivity with Diaspot (75.00\%), higher specificity (99.66\% compared to $97.20 \%$ ), higher positive predictive value, negative predictive value $(99.20 \%, 89.71 \%$ and $99.89 \%$ respectively) compared to Diaspot (97.20\%, 25.00\% and $98.50 \%$ respectively) and nine-fold DOR (1764.7) compared to Diaspot rapid enzyme immunoassay (196.1). The statistical findings of the ELISA assay were similar to those of COBAS AmpliPrep/COBAS TaqMan PCR (CAP/CTM).

Table2. Marital status and blood donation history of prospective blood donors screened for HCV antibody

\begin{tabular}{lcccc}
\hline Social Demog & Overall PBD n (\%) & VBD n (\%) & RBD n (\%) & PDBD n (\%) \\
\hline Marital Status: & $174(58.0)$ & $134(60.4)$ & $32(46.4)$ & $8(88.9)$ \\
\hline Single & $48(16.0)$ & $84(37.8)$ & $34(49.3)$ & $1(11.1)$ \\
Married & $6(2.0)$ & $3(1.4)$ & $3(4.3)$ & $0(0.0)$ \\
Widowed & $1(0.3)$ & $1(0.5)$ & $0(0.0)$ & $0(0.0)$ \\
Divorced/ Separated & & & $31(44.9)$ & $4(44.4)$ \\
Blood Donation History: & $168(56.0)$ & $132(59.5)$ & $38(55.1)$ & $5(55.6)$ \\
\hline Never Donated (First timers) & $132(44.0)$ & $90(40.5)$ & & \\
Donated (Previous Donors) & & & & \\
\hline Abbreva)
\end{tabular}

Abbreviation: VBD, Voluntary Blood Donors; RBD, Replacement Blood Donors; PDBD, Paid Blood Donors

Table 3. Statistical comparison of HCV antibody serologic screening techniques using COBAS Ampliprep/COBAS TaqMan PCR (Real-time PCR) as the gold standard

\begin{tabular}{lcccccccccc}
\hline Technique & TP & FP & TN & FN & SS & SP & PPV & NPV & DOR & Prevalence (\%) \\
DIASPOT & 1.0 & 4.0 & 295.0 & 0.0 & 100.0 & 98.7 & 20.0 & 100.0 & Infinity & 1.7 \\
Sandwich ELISA & 1.0 & 0.0 & 299.0 & 0.0 & 100.0 & 100.0 & 100.0 & 100.0 & Infinity* & 0.3 \\
CAP/CTM & 1.0 & 0.0 & 299.0 & 0.0 & 100.0 & 100.0 & 100.0 & 100.0 & Infinity* & 0.3 \\
\hline \multicolumn{8}{c}{ Computed Data for Adjusted DOR } \\
\hline Technique & TP & FP & TN & FN & SS & SP & PPV & NPV & DOR & Prevalence (\%) \\
DIASPOT & 1.5 & 4.5 & 295.5 & 0.5 & 75.0 & 98.5 & 25.0 & 98.5 & 196.1 & 1.7 \\
Sandwich ELISA & 1.5 & 0.5 & 299.5 & 0.5 & 75.0 & 99.2 & 89.7 & 99.9 & 1764.7 & 0.3 \\
CAP/CTM & 1.5 & 0.5 & 299.5 & 0.5 & 75.0 & 99.2 & 89.7 & 99.9 & 1764.7 & 0.3 \\
\hline
\end{tabular}

*Infinity means perfect test

Abbreviation: TP, True positives; TN, True Negatives; SS, Sensitivity; SP, Specificity; FP, False Positives; FN, False Negatives;

PPV, Positive Predictive Value; NNV, Negative Predictive Value; DOR, Diagnostic Odds Ratio 
Table 4. Confirmatory diagnosis hepatitis C virus with Real-time PCR

\begin{tabular}{lcccccc}
\hline $\begin{array}{l}\text { Technique } \\
\text { (Ser/Mol) }\end{array}$ & $\begin{array}{c}\text { Overall PBD } \\
\text { Screened } \\
\mathbf{n}(\%)\end{array}$ & $\begin{array}{c}\mathbf{H C V A b}^{+} \\
\mathbf{n}(\boldsymbol{\%})\end{array}$ & $\begin{array}{c}\text { HCVAb }^{-} \\
\mathbf{n}(\boldsymbol{\%})\end{array}$ & $\begin{array}{c}\text { HCV-RNA, } \\
\text { DT n }(\boldsymbol{\%})\end{array}$ & $\begin{array}{c}\text { HCV-RNA, } \\
\text { NDT N (\%) }\end{array}$ & $\begin{array}{c}\text { HCV-RNA } \\
\text { VL (IU/mL) }\end{array}$ \\
\hline Diaspot EIA & $300(100.0)$ & 5 & $295(98.33)$ & - & - & - \\
ELISA Assay & $300(100.0)$ & $1(0.33)$ & $299(99.67)$ & - & - & - \\
CAP/CTM PCR (QL) & $300(100.0)$ & - & - & $1(0.33)$ & $299(99.67)$ & - \\
CAP/CTM PCR (QQ) & $1(0.33)$ & - & - & - & - & 133,209 \\
\hline
\end{tabular}

Abbreviation: Ser, Serology; Mol, Molecular; PBD, Prospective Blood Donors; n (\%), Absolute number (Percentage); -, Not


Hepatitis C Virus antibody; HCV-RNA, Hepatitis C Virus ribonucleic acid; PCR, Polymerase Chain Reaction; CAM/CTM, COBAS Ampliprep/ COBAS TaqMan; VL, Viral load; QL, Qualitative Technique; QQ, Quantification Technique; IU/mL, International Units/ millilitre

\subsection{Confirmatory Diagnosis Hepatitis C Virus with Real-time PCR}

Of the 300 PBD screened for HCV within the study period, $5(1.67 \%)$ were seropositive with Diaspot rapid one-step enzyme immunoassay. HCV seroprevalence by ELISA technique using Genscreen $\mathrm{HCV}$ Ag-Ab Monolisa kit was $0.33 \%$ (i.e. only one seropositive case). Hence, there were four discordant results. Real-time PCR is recognized as the confirmatory test for $\mathrm{HCV}$ by detecting HCV-RNA in serum/plasma of infected persons. Further analysis of the donors' samples with COBAS Ampliprep/COBAS TaqMan PCR showed that $1(0.33 \%)$ was positive for HCV-RNA. The only HCV positive blood donor was a male VBD. Quantification of the HCV-RNA (viral load) of the confirmed donor sample showed HCV viraemia of $133,209 \mathrm{IU} / \mathrm{mL}$. Serum ALT of the blood donor was 11.1IU/L (normal range: Up to $20 \mathrm{IU} / \mathrm{mL}$ ). The results of the confirmatory and quantification assay were presented in Table 4 below.

\section{Discussion}

Of the three hundred PBD screened during the study period for HCV antibody, the results showed that almost three-quarter $222(74.0 \%)$ of the PBD were voluntary blood donors. This is line with the current advocacy of the World Health Organization for promotion of $100 \%$ voluntary blood donation ${ }^{[28-}$ 29]. The strong collaboration between Federal Teaching Hospital and functional NBTS was a contributing factor. The male: female ratio of $1: 1$ observed among the VBD in this study compared to RBD (10.5:1) and PDBD (3.5:1) could, beyond other factors, be traceable to more female first timers among the population of VBD due to the knowledge of the PBD on giving blood to save lives and recruitment benefits of having $\mathrm{HCV}$ antibody screened and confirmed without cost burden. Study finding on male: female ratio of 1:1 among VBD differed from the research outcomes of Olokoba et al. ${ }^{[30]}$. where most of the blood donors (> 98.0\%) were males. It is slightly lower than 1.1:1 reported by Mavenyengwa et al. (2014) in Namibia VBD ${ }^{[31]}$. However, male: female ratio among the RBD (10.5:1), or $91.1 \%$ male blood donors conform to those of other researchers. Discovery of lower male: female ratio (3.5) among paid blood donors compared to RBD showed some females also engaged in commercialization of blood.

The most common age group of PBD was 1625 years $(44.3 \%)$ while the least was $56-59$ years $(0.7 \%)$. Age groups of VBD followed similar pattern observed in the overall PBD screened while the pattern in RBD was slightly different. The most common age group in VBD was $16-25$ years $(48.6 \%)$ in contrast to $26-35$ years $(43.5 \%)$ among the RBD. The outcomes of Mohammed and Beleke's study which was predominantly among RBD corroborated our observations among RBD in this study while it was in contrast to the patterns among VBD ${ }^{[32]}$.

Furthermore, study showed that higher percentage of Christians than Muslims participated 
irrespective of blood donor category and that reflected the predominance of Christians in Ekiti state and their corresponding interest in giving blood to save lives. Similar study in Ilorin showed that higher percentage of Christians $(70.8 \%)$ gave blood than Muslims ${ }^{[33]}$. Most of the PBD had formal education. High percentage of educated individuals enrolled in this study irrespective of blood donor category similarly reflected the focus of the NBTS in targeted population, underlying superstitious and cultural beliefs among individuals without formal education and low public enlightenment which hinder participation in blood donation. With respect to educational levels of PBD, Shenga et al (2010) and Alfouzan et al (2014) published corroborative results showing that history of blood donation was steadily increasing with the increase in the educational level of participants 35].

Moreover, more singles (60.4\% and $88.9 \%$ ) participated as VBD and PDBD respectively compared to married persons (37.8\% and $11.1 \%$ ). These were mostly students in tertiary institutions. However, percentage of married persons among RBD was slightly higher (49.3\%) compared to that of singles $(46.4 \%)$. Overall, $58.0 \%$ were singles while $16.0 \%$ were married. This is in contrast to Alfouzan's study in Saudi Arabia who reported that married individuals had higher blood donation knowledge level compared to singles ${ }^{[35]}$. Other authors reported varied conclusions ${ }^{[36-37]}$. The outcomes of this study based on donation status revealed that more first timers than previous donors participated as VBD. However, more previous donors enrolled as RBD (55.1\%) and PDBD $(55.6 \%)$ compared to first timers $(44.9 \%)$ and $44.4 \%$ ) in RBD and PDBD respectively.

The consistent observations of higher percentages of VBD among the overall population screened as well as higher percentages of younger age groups (16-25 years in VBD), nearly 1:1 male: female ratio and those with tertiary education showed that achieving $100 \%$ voluntary blood donation in Nigeria is a great possibility if each health institution can have a workable collaborative policy with established functional and well-funded NBTS in each state in Nigeria ${ }^{[29]}$. A study in an Indian blood bank showed achievement of $88.0 \%$ compared to the national average of $39.3 \%$ voluntary blood donation ${ }^{[38]}$. Their success was similarly attributed to active motivational outreach to educational institutes through public lectures, presentations, posters and pamphlets thus recruiting long-term young donors. Several studies have demonstrated recruitment of more male donors than females [38-39,30]. Reports by the World Health Organization also stated that less than $10 \%$ of blood is given by women in resource-poor countries ${ }^{[28]}$.

The observed false positive results, hence, higher HCV antibody seroprevalence (1.67\%) by Diaspot rapid enzyme immunoassay compared to that of Biorad Genscreen HCV Ag-Ab Monolisa assay $(0.33 \%)$ based on 'sandwich' ELISA technique in this study contrast the outcomes of studies by other researchers who found false negative results using Diaspot rapid one-step enzyme immunoassay ${ }^{[18]}$. Current trends in transfusion service demand that initial screening of blood and blood products be based on ELISA technique using kit that both screen for the HCV core antigen and anti-HCV antibodies that improves early detection of $\mathrm{HCV}$ infection during the window period and subsequent confirmation of HCV status with recombinant immunoblotting assay (RIBA) or nucleic acid testing (NAT) by real-time PCR ${ }^{[40-42]}$. Literatures have showed that continued development of newer testing techniques have helped to significantly improve early detection and reduce the window period from 82 days to 66 days and even lower ${ }^{[43]}$. Genscreen HCV Ag-Ab Monolisa assay has been proved in a study by Laperche to reduce the window period of detection by 21.6 days and 30.1 days when compared to the most sensitive immunoassays and Monolisa $\mathrm{HCV}$ Ab. Assay ${ }^{[42]}$. It is interesting to note that combined detection of $\mathrm{HCV}$ core antigen and anti-HCV antibodies has significantly closed the gap of detection between most sensitive HCV antibody assays and NAT thus making it a useful alternative to costly real-time PCR procedure in resourcelimited countries for enhancing 'safe blood' practice. This is the first time in Ekiti state that $\mathrm{HCV}$ testing in PBD was advanced to include nucleic acid testing by real-time PCR to enhance safe blood practice and give evidence-based report on HCV endemicity in Ekiti state. HCV 
seroprevalence of $0.33 \%$ reported in this study based on Monolisa HCV Ag-Ab technique, ELISA assay (in contrast to $1.67 \%$ by Diaspot) was confirmed with real-time PCR. None of the seronegative samples was positive by the reference technique. Based on its lower specificity and positive predictive value $(98.7 \%$ and $20.0 \%$ respectively) compared to $100.0 \%$ for both specificity and positive predictive value by ELISA technique, Diaspot one step EIA cannot be depended upon as the sole technique for diagnosing HCV. This study outcomes corroborated the manufacturer's claims of sensitivity $>99.0 \%$ and specificity of $98.6 \%$.

Undefined DOR by Genscreen $\mathrm{HCV} \mathrm{Ag}-\mathrm{Ab}$ Monolisa assay (Biorad HCV Ag-Ab ULTRA Monolisa assay, Marnes la Coquette, France) with both false positives and false negatives being zero implied a perfect test. However, similar statistical finding by Diaspot kit with only false positives showed the need for improvement ${ }^{[44,47]}$. Adjusted DOR further elucidated the need to avoid using rapid test kits as sole diagnostic tool for screening blood as they are not specific enough. Genscreen $\mathrm{HCV}$ Ag-Ab Monolisa assay showed 9-fold better performance than Diaspot one-step enzyme immunoassay based on adjusted DOR. The implication is that blood donors that would have otherwise been certified fit for blood donation would be excluded on the basis of false positive anti-HCV result leading to more shortage of blood and sometimes psychological and emotional trauma in the blood donors. Other researchers found it was not sensitive enough and should not be used for blood screening ${ }^{\text {[45-46]. }}$.

$\mathrm{HCV}$ diagnosis was advanced to molecular level with the use of real-time PCR assay to resolve serodiscordant findings from Diaspot and ELISA. Elevated (1.67\%) HCV antibody seroprevalence given by Diaspot one-step rapid immunochromatographic technique compared to $0.33 \%$ by ELISA procedure validated by real-time PCR assay revealed the challenges associated with rapid techniques without a well-defined algorithm such as that available for HIV diagnosis [47-48]. Majority of laboratories in Nigeria are without ELISA facility and as such depend on rapid enzyme immunoassay procedure (especially Diaspot one- step EIA) for HCV screening in blood donors ${ }^{[18,49]}$. While Adeyemi et al reported less sensitivity of Diaspot EIA in their article, this study showed the lower specificity of the procedure compared to ELISA technique. The reason for the differences in this study outcome and theirs remain unclear but may not be far from the deterioration of the kit due to improper storage in previous studies. Findings in this study corroborated the manufacturer's claim of its sensitivity (99.7\%) and specificity (98.6\%). Confirmation with real-time PCR validated the seropositivity of the lone sample $(0.33 \%)$ while the rest (ran in minipools of two samples) showed undetected HCV-RNA. Nucleic acid testing with highly sensitive molecular technique such as the real-time PCR which can detect as low as 5-30 $\mathrm{IU} / \mathrm{mL}$ of HCV-RNA has been considered the preferred and gold standard technique for $\mathrm{HCV}$ confirmation and remain the mainstay in $\mathrm{HCV}$ diagnosis but it is very costly ${ }^{[47-50]}$. NAT for HCVRNA in blood donors has dramatically reduced the incidence of post-transfusion hepatitis $\mathrm{C}$ with the risk of $\mathrm{HCV}$ acquisition dropping from 1 per 276,000 to 1 per 2 million donations ${ }^{[51-52]}$. HCV prevalence in lone VBD confirmed in this study was $0.33 \%$. This was higher than $0.1 \%$ reported by Mavenyengwa and his co-researchers in similar study in Namibia ${ }^{[31]}$ but lower than $0.4 \%$ in an Ethiopian study ${ }^{[32]}$ and significantly lower than $6.1 \%$ reported by Damulak among blood donors in Jos, Nigeria ${ }^{[53]}$. Differences in HCV prevalence by authors in various part of the world showed that geographical locations, mode of infections, cultural practices, and prevalent risk factors might all be responsible ${ }^{[12]}$.

Furthermore, HCV quantification and serum alanine aminotransferase results of the blood donor $(133,209 \mathrm{IU} / \mathrm{mL}$ and $11.1 \mathrm{IU} / \mathrm{L}$ respectively) demonstrated a typical diagnosis of chronic carrier of hepatitis $C$ virus.

The VBD's status history revealed that the $\mathrm{HCV}$ infection was first diagnosed in an asymptomatic phase with rapid enzyme immunoassay technique $7-8$ years ago during a routine medical test. Serum ALT was within normal limit $(<30 \mathrm{U} / \mathrm{L})$. Due to limited resources, HCVRNA confirmation and quantification could not be performed then. A study documented a cut-off of 
$800,000 \mathrm{IU} / \mathrm{mL} \mathrm{HCV}$ viraemia ${ }^{[54]}$ irrespective of serum ALT values for initiating antiviral therapy in infected patient/donors while other studies recommended pre-treatment baseline HCV-RNA level of $400,000 \mathrm{IU} / \mathrm{mL}{ }^{[55-56]}$. Serum alanine aminotransferase $>19 \mathrm{U} / \mathrm{L}$ in female and $>30 \mathrm{U} / \mathrm{L}$ in male donors together with elevated HCV-RNA levels $(>400,000 \mathrm{IU} / \mathrm{mL})$ is an essential condition for initiating therapy. While therapy might not be initiated in the VBD based on the aforementioned recommendations, quarterly monitoring of serum ALT and HCV viral load may be necessary. In contrast, current guidelines by the American Association for the Study of Liver (AASLD) in collaboration with Infectious Diseases Society of America (IDSA) on "When and in whom to initiate $\mathrm{HCV}$ therapy" recommended that antiviral therapy be initiated for all categories of patients ${ }^{[57]}$. Sustained virologic response (SVR), evidence of virologic cure, is the end point of successful hepatitis C treatment. An SVR is defined as the continued absence of detectable HCV-RNA at least 12 weeks after completion of therapy [58-60]. Detection of anti-HCV antibodies is still a possibility when SVR has been achieved in a blood donor treated for $\mathrm{HCV}$ infection but such blood donor will no longer have detectable HCV-RNA in serum, peripheral blood mononuclear cells (PBMC) or liver tissue and achieve significant improvement in liver architecture [60]. Actually, treatment decisions by the physicians are based on some vital pieces of information including (but not limited to) unique patient populations (e.g. patients with decompensated cirrhosis, renal impairment, $\mathrm{HIV} / \mathrm{HCV}$ or $\mathrm{HBV} / \mathrm{HCV}$ co-infections and those who develop recurrent $\mathrm{HCV}$ infection following liver transplantation) and pre-treatment assessment of patient's understanding of the goals of therapy as well as the need for adherence and follow up. Studies have shown that reduction in severity of disease and eventual cure for HCV contribute to dramatic reduction in all-cause mortality (including hepatic decompensation events, hepatocellular carcinoma and liver-related mortality) and improve quality of life ${ }^{[61-66]}$. Dhawan documented various drug regimens for the treatment of hepatitis $C^{[67]}$.

\section{Conclusion}

HCV prevalence among prospective blood donors in Ekiti state is low and optimal diagnosis of $\mathrm{HCV}$ infection in PBD should consider testing approach that screen simultaneously for $\mathrm{HCV}$ core antigen and anti-HCV antibodies as the starting point and subsequent HCV-RNA confirmation and quantification for donors' healthcare benefits. For blood safety purpose in resource-limited setting, $\mathrm{HCV} \mathrm{Ag/Ab} \mathrm{testing} \mathrm{can} \mathrm{be} \mathrm{the} \mathrm{starting} \mathrm{and} \mathrm{stopping}$ point. Diaspot rapid EIA cannot be depended upon as a diagnostic tool due to lower specificity. To enhance blood safety practice, policy formulation that target $100 \%$ voluntary blood donation is strongly recommended for blood transfusion laboratories so as to conform to international standards.

\section{Authorship Contributions}

AGI designed the work, revised the manuscripts, and made scientific inputs. FKA wrote the manuscript, sourced for literatures and performed the analyses. IMO made strong statistical input, corrected the manuscripts and was also involved in the design of the study.

\section{Disclosure of Conflict of interests}

Authors declare that there is no conflict of interest with regard to this study.

\section{References}

1. Trucchi C, Orsi A, Alicino C, Sticchi L, Icardi G, Ansaldi F. State of the Art, Unresolved Issues, and Future Research Directions in the Fight against Hepatitis C Virus: Perspectives for Screening, Diagnostics of Resistances, and Immunization. J Immunol Res 2016; 2016: 1412840 [PMID: 27843956 PMCID: PMC5098088 DOI: 10.1155/2016/1412840]

2. Alter MJ. Epidemiology of hepatitis C virus infection. World J Gastroenterol 2007; 13(17): 2436-2441 [PMID: 17552026 PMCID: PMC4146761] 
3. Penin F. Structural biology of hepatitis $\mathrm{C}$ virus. Clin Liver Dis 2003; 7(1): 1-21, vii [PMID: 12691456]

4. Karoney MJ, Siika AM. Hepatitis C virus (HCV) infection in Africa: a review. Pan Afr Med J 2013; 14: 44 [PMID: 23560127 PMCID: PMC3612901

DOI:

10.11604/pamj.2013.14.44.2199]

5. Ilina EN, Malakhova MV, Generozov EV, Nikolaev EN, Govorun VM. Matrix-assisted laser desorption ionization-time of flight (mass spectrometry) for hepatitis $\mathrm{C}$ virus genotyping. J Clin Microbiol 2005; 43(6): 2810-2815 [PMID: 15956402 PMCID: PMC1151883 DOI: 10.1128/JCM.43.6.2810-2815.2005]

6. Forbi JC, Purdy MA, Campo DS, Vaughan G, Dimitrova ZE, Ganova-Raeva LM, Xia GL, Khudyakov YE. Epidemic history of hepatitis $\mathrm{C}$ virus infection in two remote communities in Nigeria, West Africa. J Gen Virol 2012; 93(Pt 7): 1410-1421 [PMID: 22456613 PMCID: PMC4591030 DOI: 10.1099/vir.0.042184-0]

7. Saleem K, Jan D, Aufra C et al. Laboratory Diagnostics for HCV Virus Infection. Clinical Infectious Disease 2012; 55 (1):S43-48. [DOI: 10.1093/cid/cis368.]

8. Coito C, Diamond DL, Neddermann P, Korth MJ, Katze MG. High-throughput screening of the yeast kinome: identification of human serine/threonine protein kinases that phosphorylate the hepatitis C virus NS5A protein. J Virol 2004; 78(7): 3502-3513 [PMID: 15016873 PMCID: PMC371080]

9. Cormier EG, Tsamis F, Kajumo F, Durso RJ, Gardner JP, Dragic T. CD81 is an entry coreceptor for hepatitis C virus. Proc Natl Acad Sci U S A 2004; 101(19): 7270-7274 [PMID: $15123813 \quad$ PMCID:PMC409908 DOI:10.1073/pnas.0402253101]

10. Luzano R, Naghavi $M$, Foreman $K$ et al. Global and regional mortality from 235 causes of death for 20 age groups in 1990 and 2010: a systematic analysis for the Global Burden of Disease Study 2010. Lancet 2012; 380(9859): 2095-2128 [PMID: 23245604 DOI: 10.1016/S0140-6736(12)61728-0]

11. World Health Organization. Updated Fact sheet Hepatitis B and C. WHO, 2013. Geneva.
12. Gasim GI, Murad IA, Adam I. Hepatitis B and $\mathrm{C}$ virus infections among pregnant women in Arab and African countries. J Infect Dev Ctries 2013; 7(8): 566-578 [PMID: 23949291 DOI: $10.3855 /$ jidc.3243]

13. Xia X, Luo J, Bai J, Yu R. Epidemiology of hepatitis $\mathrm{C}$ virus infection among injection drug users in China: systematic review and meta-analysis. Public Health 2008; 122(10): 990-1003 [PMID: 18486955 DOI: 10.1016/j.puhe.2008.01.014]

14. Jafari S, Copes R, Baharlou S, Etminan M, Buxton J. Tattooing and the risk of transmission of hepatitis $\mathrm{C}$ : a systematic review and meta-analysis. Int $J$ Infect Dis 2010; 14(11): e928-940 [PMID: 20678951 DOI: 10.1016/j.ijid.2010.03.019]

15. Tohme RA, Holmberg SD. Is sexual contact a major mode of hepatitis $\mathrm{C}$ virus transmission? Hepatology 2010; 52(4): 1497-1505 [PMID: 20635398 DOI: 10.1002/hep.23808]

16. Owusu-Ofori S, Temple J, Sarkodie F et al. Predonation screening of blood donors with rapid tests: implementation and efficacy of a novel approach to blood safety in resource-poor settings. Transfusion 2005; 45(2):133-140. [DOI:10.1111/j.1537-2995.2004.04279.x]

17. Zaheer H, Saeed U, Waheed Y et al. Prevalence and trends of hepatitis B, hepatitis $\mathrm{C}$ and human immunodeficiency viruses among blood donors in Islamabad, Pakistan 2005-2013. Journal of Blood Disorders and Transfusion 2014; 5:217. [DOI:10.4172/21559864.1000217.]

18. Adeyemi AA, Omolade OA and RaheemAdemola RR. Immunochromatographic Testing Method for Hepatitis B, C in Blood Donors. Journal of Antivirals and Antiretrovirals 2013; 5:S3-4. [DOI:10.4172/jaa.S3-005.]

19. Klevens RM, Hu DJ, Jiles R, Holmberg SD. Evolving epidemiology of hepatitis $\mathrm{C}$ virus in the United States. Clin Infect Dis 2012; 55 Suppl 1: S3-9 [PMID: 22715211 DOI: 10.1093/cid/cis393]

20. Meena M, Jindal T, Hazarika A. Prevalence of hepatitis $B$ virus and hepatitis $C$ virus among blood donors at a tertiary care hospital in India: 
a five-year study. Transfusion 2011; 51(1): 198-202 [PMID: 20663107 DOI: 10.1111/j.1537-2995.2010.02801.x]

21. Ayolabi CI, Taiwo MA, Omilabu SA et al. Sero-prevalence of hepatitis $\mathrm{C}$ virus among blood donors in Lagos, Nigeria. African Journal of Biotechnology 2006; 5 (20):19441946.

22. Chukwurah EF, Ogbodo SO and Obi GO. Seroprevalence of Hepatitis C Virus (HCV) infection among blood donors in a SouthEastern State of Nigeria. Biomedical Research 2005; 16 (2): 133-135.

23. Odenigbo C, Oguejiofor C, Okwonkwo U. et al. Prevalence of Antibodies to Hepatitis C Virus in Blood Donors in Nnewi, South-Eastern Nigeria; In Association with Blood Groups. The Internet Journal of Gastroenterology 2010; 10 (2):1-9.

24. Buseri FI, Muhibi MA, Jeremiah ZA. Seroepidemiology of transfusion-transmissible infectious diseases among blood donors in Osogbo, south-west Nigeria. Blood Transfus 2009; 7(4): 293-299 [PMID: 20011640 PMCID: PMC2782806 DOI: 10.2450/2009.0071-08]

25. Erhabor O, Ejele OA, Nwauche CA. The risk of transfusion-acquired hepatitis-C virus infection among blood donors in Port Harcourt: the question of blood safety in Nigeria. Niger $J$ Clin Pract 2006; 9(1): 18-21 [PMID: 16986284]

26. Clinical and Laboratory Standard Institute. Tubes and additives for venous blood specimen collection. Approved guideline-fifth edition. HI-A5 2003; 16(13): 45 - 56.

27. Glas AS, Lijmer JG, Prins MH, Bonsel GJ, Bossuyt PM. The diagnostic odds ratio: a single indicator of test performance. J Clin Epidemiol 2003; 56(11): 1129-1135 [PMID: 14615004]

28. World Health Organization (2011). Sixty-third world health assembly on viral hepatitis infection. WHO 2011. Geneva.

29. World Health Organization (2015). Guidelines on assessing donor's suitability for blood donation. WHO Geneva.
30. Olokoba AB, Salawu F, Danburam A et al. Viral hepatitides in voluntary blood donors in Yola, Nigeria. European Journal of Scientific Research 2009; 31(3): 329-324.

31. Mavenyengwa RT, Mukesi M, Chipare I, Shoombe E. Prevalence of human immunodeficiency virus, syphilis, hepatitis B and $\mathrm{C}$ in blood donations in Namibia. BMC Public Health 2014; 14: 424 [PMID: 24884633 PMCID: PMC4012713 DOI: 10.1186/1471-2458-14-424]

32. Mohammed Y, Bekele A. Seroprevalence of transfusion transmitted infection among blood donors at Jijiga blood bank, Eastern Ethiopia: retrospective 4 years study. BMC Res Notes 2016; 9: 129 [PMID: 26922241 PMCID: PMC4769562 DOI: 10.1186/s13104-0161925-6]

33. Salaudeen AG, Odeh E. Knowledge and behavior towards voluntary blood donation among students of a tertiary institution in Nigeria. Niger J Clin Pract 2011; 14(3): 303 307 [PMID: 22037074 DOI: 10.4103/11193077.86773]

34. Shenga N, Thankappan K, Kartha C et al. Analysing social demographic factors amongst blood donors. Journal of Emergencies, Trauma, and Shock 2010; 3:21-25.

35. Alfouzan N. Knowledge, Attitudes, and Motivations towards Blood Donation among King Abdulaziz Medical City Population. Int J Family Med 2014; 2014: 539670 [PMID: 25431668 PMCID: PMC4238271 DOI: $10.1155 / 2014 / 539670]$

36. Kulkarni P, Kulkarni A. Mass counseling: effective tool to improve knowledge, attitude and behavior regarding blood donation. Ann Med Health Sci Res 2014; 4(1): 90-94 [PMID: 24669338 PMCID: PMC3952305 DOI: 10.4103/2141-9248.126609]

37. Maghsudlu M, Nasizadeh S. Iranian blood donors' motivations and their influencing factors. Transfus Med 2011; 21(4): 247-252 [PMID: 21672058 DOI: 10.1111/j.13653148.2011.01077.x]

38. Sareen R, Gupta GN and Dutt A. Donor awareness: key to successful voluntary donation [version 1 referees: 2 approved 
reservations].

F1000Research

2012;1:29.[DOI:10.1155/2014/539670.]

39. Lavanya V, Viswanathan TS, Arul Sheeba MS, Malarvizhi A and Moorthy K. (2012). Prevalence of hepatitis B virus infection among blood donors with antibodies to hepatitis B core antigen. International Journal of Medicine and Medical Sciences 2012; $4 \quad$ (6): $\quad 128 \quad-137$. [DOI:10.5897/IJMMS12.011.]

40. Zauli DA, Menezes CL, Oliveira CL, Mateo EC, Ferreira AC. In-house quantitative realtime PCR for the diagnosis of hepatitis B virus and hepatitis $\mathrm{C}$ virus infections. Braz J Microbiol 2016; 47(4): 987-992 [PMID: 27637170 PMCID: PMC5052370 DOI: 10.1016/j.bjm.2016.07.008]

41. Clancy A, Crowley B, Niesters H, Herra C. The development of a qualitative real-time RTPCR assay for the detection of hepatitis $\mathrm{C}$ virus. Eur J Clin Microbiol Infect Dis 2008; 27(12): 1177-1182 [PMID: 18551325 DOI: 10.1007/s10096-008-0556-9]

42. Laperche S, Le Marrec N, Girrault S et al. Simultaneous Detection of Hepatitis C Virus (HCV) Core Antigen and Anti-HCV Antibodies Improves the Early Detection of HCV Infection. Journal of Clinical Microbiology 2005; 43 (8): 3877 - 3883. [DOI: 10.1128/JCM.43.8.3877-3883.]

43. Busch M. Closing the windows on viral transmission by blood transfusion, p33-54. In: S.L. Stramer (ed.), Blood safety in the new millennium. American Association of Blood Banks 2001; Bethesda, Md.

44. Huang Y, Yin J and Samawi H. Methods for improving the estimate of diagnostic odds ratio. Journal of Communications in StatisticsSimulation and Computation 2016; 0:1.

45. Sreedhar BKV, Chaitanya KIS, Yashovarhan A et al. Evaluation of Immunochromatographic and ELISA Methods in detection of Anti-HCV antibodies among Healthy Blood Donors; A Pilot Study. Journal of Clinical Science Research 2012; 1:110-111.

46. Khan JK,Lones DS, Hameed A et al. Evaluation of the performance of two Rapid Immunochromatographic test for Detection of
Hepatitis B Surface Antigen and Anti-HCV Antibodies using ELISA Tested Samples. Annals of King Edward Medical University 2010: 16: 84-7.

47. Centre for Disease Control and Prevention: Rapid HIV Testing in Outreach and other Community settings-United States, 2004-2006. Morbidity and Mortality Weekly Report 2007; 56 (47): 1233-37

48. World Health Organization (2004). Rapid HIV tests: guidelines for use in HIV testing and counselling services in resource constrained settings. Available from: www.emro.who.int/aiecf/web28.pdf

49. Opaleye OO, Salami SF, Familua F et al. Seroprevalence of Hepatitis B Surface Antigen and Antibody among Pregnant Women Attending a Tertiary Health Institution in South-western Nigeria. IOSR Journal of Dental and Medical Sciences 2014; 13; 3(1):67-71.

50. Scott JD, Gretch DR. Molecular diagnostics of hepatitis $\mathrm{C}$ virus infection: a systematic review. JAMA 2007; 297(7): 724-732 [PMID: 17312292 DOI: 10.1001/jama.297.7.724]

51. Chevaliez S, Pawlotsky JM. Hepatitis C virus serologic and virologic tests and clinical diagnosis of HCV-related liver disease. Int J Med Sci 2006; 3(2): 35-40 [PMID: 16614740 PMCID: PMC1415842]

52. Stramer SL, Glynn SA, Kleinman SH, Strong DM, Caglioti S, Wright DJ, Dodd RY, Busch MP, National Heart L, Blood Institute Nucleic Acid Test Study G. Detection of HIV-1 and $\mathrm{HCV}$ infections among antibody-negative blood donors by nucleic acid-amplification testing. N Engl J Med 2004; 351(8): 760-768 [PMID: 15317889 DOI: 10.1056/NEJMoa040085]

53. Damulak OD, Piwuna TO, Joseph DE et al. Hepatitis C Virus antibody among blood donors: The experience in a Nigerian Blood Transfusion Service Centre. Global Advanced Research Journal of Medicine and Medical Sciences 2013; 2 (5): 108 -113.

54. Zeuzem S, Berg T, Moeller B, Hinrichsen H, Mauss S, Wedemeyer H, Sarrazin C, Hueppe D, Zehnter E, Manns MP. Expert opinion on the 
treatment of patients with chronic hepatitis C. J Viral Hepat 2009; 16(2): 75-90 [PMID: 18761607 PMCID: PMC2759987 DOI: 10.1111/j.1365-2893.2008.01012.x]

55. Zeuzem S, Fired MW and Reddy KR. Improving the clinical relevance of pretreatment viral load as a predictor of sustained virological response (SVR) in patients infected with hepatitis $\mathrm{C}$ genotype 1 treated with peginterferon alfa-2a (40kd) (PEGASYS) plus ribavirin (COPEGUS). Hepatology 2006; 44 (1): $267 \mathrm{~A}$.

56. Berg $T$, von Wagner $M$ and Hinrichsen $H$. Definition of a pre-treatment viral load cut-off for an optimized prediction of treatment outcome in patients with genotype 1 infection receiving either 48 or 72 weeks of peginterferon alfa-2a plus ribavirin. Hepatology 2006; 44 (1): 321A.

57. American Association for the Study of Liver Diseases and the Infectious Disease Society of America. HCV Guidance: Recommendations for Testing, Managing, and Treating Hepatitis C. $2017 . \quad$ Available at: http://www.hcvguidelines.org/full-report-view (Accessed February 6, 2017).

58. Manns MP, Pockros PJ, Norkrans G, Smith CI, Morgan TR, Haussinger D, Shiffman ML, Hadziyannis SJ, Schmidt WN, Jacobson IM, Barcena R, Schiff ER, Shaikh OS, Bacon B, Marcellin P, Deng W, Esteban-Mur R, Poynard T, Pedicone LD, Brass CA, Albrecht JK, Gordon SC. Long-term clearance of hepatitis C virus following interferon alpha-2b or peginterferon alpha-2b, alone or in combination with ribavirin. J Viral Hepat 2013; 20(8): 524-529 [PMID: 23808990 DOI: 10.1111/jvh.12074]

59. Swain MG, Lai MY, Shiffman ML, Cooksley WG, Zeuzem S, Dieterich DT, Abergel A, Pessoa MG, Lin A, Tietz A, Connell EV, Diago M. A sustained virologic response is durable in patients with chronic hepatitis $\mathrm{C}$ treated with peginterferon alfa-2a and ribavirin. Gastroenterology 2010; 139(5): 1593-1601 [PMID: $20637202 \quad$ DOI: 10.1053/j.gastro.2010.07.009]
60. Coppola N, De Pascalis S, Pisaturo M, Paradiso L, Macera M, Capoluongo N, Alessio L, Stanzione M, Sagnelli C, Minichini C, Sagnelli E. Sustained virological response to antiviral treatment in chronic hepatitis $\mathrm{C}$ patients may be predictable by HCV-RNA clearance in peripheral blood mononuclear cells. J Clin Virol 2013; 58(4): 748-750 [PMID: $24140030 \quad$ DOI: 10.1016/j.jcv.2013.09.014]

61. Sise ME, Bloom AK, Wisocky J, Lin MV, Gustafson JL, Lundquist AL, Steele D, Thiim M, Williams WW, Hashemi N, Kim AY, Thadhani R, Chung RT. Treatment of hepatitis $\mathrm{C}$ virus-associated mixed cryoglobulinemia with direct-acting antiviral agents. Hepatology 2016; 63(2): 408-417 [PMID: 26474537 PMCID: $\quad$ PMC4718772 DOI: 10.1002/hep.28297]

62. Hussein NR, Saleem ZS. Successful Treatment of Hepatitis C Virus Genotype 4 in Renal Transplant Recipients With Direct-Acting Antiviral Agents. Am J Transplant 2016; 16(7): 2237-2238 [PMID: 26932513 DOI: 10.1111/ajt.13767]

63. Morgan RL, Baack B, Smith BD, Yartel A, Pitasi M, Falck-Ytter Y. Eradication of hepatitis $\mathrm{C}$ virus infection and the development of hepatocellular carcinoma: a meta-analysis of observational studies. Ann Intern Med 2013; 158(5 Pt 1): 329-337 [PMID: 23460056 DOI: 10.7326/0003-4819-158-5-201303050-00005]

64. van der Meer AJ, Veldt BJ, Feld JJ, Wedemeyer H, Dufour JF, Lammert F, Duarte-Rojo A, Heathcote EJ, Manns MP, Kuske L, Zeuzem S, Hofmann WP, de Knegt RJ, Hansen BE, Janssen HL. Association between sustained virological response and all-cause mortality among patients with chronic hepatitis $\mathrm{C}$ and advanced hepatic fibrosis. JAMA 2012; 308(24): 2584-2593 [PMID: 23268517 DOI: 10.1001/jama.2012.144878]

65. Dienstag JL, Ghany MG, Morgan TR, Di Bisceglie AM, Bonkovsky HL, Kim HY, Seeff LB, Szabo G, Wright EC, Sterling RK, Everson GT, Lindsay KL, Lee WM, Lok AS, Morishima C, Stoddard AM, Everhart JE, Group H-CT. A prospective study of the rate of 
progression in compensated, histologically advanced chronic hepatitis C. Hepatology 2011; 54(2): 396-405 [PMID: 21520194 PMCID: PMC3144992 DOI: 10.1002/hep.24370]

66. Boscarino JA, Lu M, Moorman AC, Gordon SC, Rupp LB, Spradling PR, Teshale EH, Schmidt MA, Vijayadeva V, Holmberg SD, Chronic Hepatitis Cohort Study I. Predictors of poor mental and physical health status among patients with chronic hepatitis $\mathrm{C}$ infection: the Chronic Hepatitis Cohort Study (CHeCS). Hepatology 2015; 61(3): 802-811 [PMID: 25203533 DOI: 10.1002/hep.27422]

67. Dhawan VK. Hepatitis C Treatment and Management: Approach Considerations. Available at: http://www.emedicine.medscape.com/article/1 77792-treatment (Accessed February 6, 2017). 